\title{
PENGARUH KUALITAS PELAYANAN DAN KEPUASAN PASIEN TERHADAP LOYALITAS PASIEN RAWAT INAP DI RUMAH SAKIT TIARA PEMATANGSIANTAR
}

\author{
Oleh: \\ Nina Wardani \\ S1 Manajemen \\ Darwin Lie, Marisi Butarbutar, Efendi
}

Abstraksi

Penelitian ini dilakukan dengan menggunakan desain penelitian lapangan dan kepustakaan. Adapun sampel penelitian ini adalah pasien rawat inap di rumah sakit Tiara sebanyak 183 pasien. Pengumpulan data dilakukan dengan observasi, wawancara, dan kuesioner. Teknik analisis yang digunakan ialah regresi linear berganda, koefisien korelasi dan determinasi, dan pengujian hipotesis dengan uji F dan uji t. Hasil dari penelitian disimpulkan sebagai berikut: 1 . Kualitas pelayanan yang diberikan baik, kepuasan pasien yang dirasakan sudah tinggi dan loyalitas pasien juga tinggi. 2. Hasil analisis regresi linear berganda adalah $\hat{Y}=9,435+0,428 X 1+$ $0,267 \mathrm{X} 2$, artinya kualitas pelayanan berpengaruh positif terhadap loyalitas pasien. 3 . Hasil analisis korelasi diperoleh nilai $r=0,705$ artinya, terdapat hubungan yang kuat dan positif antara kualitas pelayanan, kepuasan dan loyalitas pasien rawat inap di rumah sakit Tiara Pematangsiantar. 4. Hipotesis penelitian $\mathrm{H}_{\mathrm{o}}$ ditolak artinya, kualitas pelayanan dan kepuasan berpengaruh positif dan signifikan terhadap loyalitas pasien rawat inap di RS Tiara Pematangsiantar secara simultan maupun parsial.

Adapun saran dari penelitian ini adalah untuk kualitas pelayanan di RS Tiara masih terdapat indikator yang rendah, untuk itu RS Tiara Pematangsiantar harus menambah peralatan medis yang lebih lengkap dan tenaga medis lebih rutin mengikuti seminar/pelatihan. Selanjutnya kepuasan masih terdapat indikator yang rendah yaitu penetapan harga perlu diperhatikan dan dibandingkan dengan harga-harga di RS lainnya agar pasien tetap loyal pada rumah sakit Tiara Pematangsiantar. Sedangkan loyalitas pasien rawat inap di rumah sakit Tiara Pematangsiantar masih terdapat indikator yang belum optimal yaitu indikator menunjukkan kekebalan terhadap pesaing agar lebih ditingkatkan keunggulan dari rumah sakit Tiara Pematangsiantar.

Kata kunci: Kualitas Pelayanan, Kepuasan dan Loyalitas

\section{Abstraction}

This research was conducted using the design of field research and literature. The sample of this research is patient hospital Tiara as many 183 patients. Data collected by observation, interviews, questionnaires and documentation. The analysis technique is using multiple linier regression, coefficient of correlation and determination, and hypothesis testing with $F$ test and t test. Results of the study can summarized as follows: 1. Quality of service provided is good, patient satisfaction is high and feel loyalty is also high. 2. Results of multiple linier regression analysis was $\hat{Y}=9,435+0,428 X 1+0,267 X 2$, it means that service quality has positive influence on patient loyalty. 3. The results of correlation values of $r=0,705$, means there is a strong and positive relationship between service quality, satisfaction and loyalty inpatiens in hospitals Tiara Pematngsiantar. 4. Research hypothesis $H_{o}$ meaning that the quality of service and satisfaction of positive and significant impact on loyalty inpatients in hospitals Tiara simultaneously and partially.

The suggestion of this research is to quality of care in hospitals Tiara indicators were lower still, to the hospital Tiara must add medical equipment more complete and more routine medical personnel to attend seminars/trainings. Furthermore, there are indicators of satisfaction low, pricing need to be considered and compared to the prices in the price of other hospitals so that patients remain loyal to the hospitals Tiara Pematangsiantar. While loyalty inpatients in hospitals Tiara Pematngsiantar, there are indicators that are not optimal indicator shows immunity against competitors to be more improved excellence of hospitals Tiara Pematangsiantar.

Keyword: Quality of Service, Satisfaction and Loyalty

\section{A. PENDAHULUAN}

\section{Latar Belakang Masalah}

Rumah sakit Tiara Pematangsiantar merupakan rumah sakit swasta yang termasuk rumah sakit tipe C, menurut Peraturan Menteri Kesehatan RI Nomor: HK.02.03/I/0501/2015. Adapun jumlah data pasien rawat inap di Rumah sakit Tiara Pematangsiantar dari bulan Januari sampai dengan bulan Desember tahun 2014 adalah sebesar 3.950 pasien dengan rata-rata perbulan sebanyak 329 pasien. Dari jumlah tersebut pasien yang berulang untuk melakukan perobatan adalah sebanyak 6 pasien perbulannya atau sebesar $2 \%$ perbulannya yang dinilai masih terlalu rendah. Rumah sakit Tiara Pematangsiantar juga memberikan produk jasa kepada pasien untuk melakukan cek up. Loyalitas pasien tergantung terhadap kualitas pelayanan yang diberikan pihak Rumah sakit terhadap pasien.

Dalam meningkatkan kualitas pelayanan Rumah sakit Tiara perlu didukung oleh sistem 
pengarsipan data (rekam medis) pasien yang handal (reability). Para karyawan medis atau non medis dapat memberikan rasa percaya (assurance). Keinginan dari para karyawan medis atau non medis untuk merespon keluhan-keluhan para pasien dengan tanggap (responsiveness). Bukti fisik (tangibles) meliputi peralatan/perlengkapan medis, sarana komunikasi, ruang tunggu bagi keluarga pasien. Rumah sakit Tiara memberikan kemudahan pelayanan dalam melakukan hubungan perhatian pribadi dan memahami kebutuhan pasien (emphaty). Tujuan pelayanan ini dilakukan untuk menciptakan kepuasan bagi pasien.

Terjadinya kepuasan pasien karena adanya pasien yang mengevaluasi jasa yang diberikan pihak rumah sakit dan pelayanan yang diberikan berkualitas bagi pasien. Pelayanan yang berkualitas diberikan harga yang cukup terjangkau, misalnya harga pemeriksaan penunjang kesehatan, honor visite dokter, dan tarif kamar bangsal sampai kelas VIP (very impotant person).

\section{Rumusan Masalah}

a. Bagaimana gambaran kualitas pelayanan, kepuasan pasien dan loyalitas pasien rawat inap pada Rumah sakit Tiara Pematangsiantar?

b. Bagaimana pengaruh kualitas pelayanan dan kepuasan pasien terhadap loyalitas pasien rawat inap di Rumah sakit Tiara Pematangsiantar secara simultan maupun parsial?

\section{Tujuan Penelitian}

a. Untuk mengetahui gambaran kualitas pelayanan, kepuasan pasien dan loyalitas pasien rawat inap di Rumah sakit Tiara Pematangsiantar.

b. Untuk mengetahui pengaruh kualitas pelayanan dan kepuasan pasien terhadap loyalitas pasien rawat inap di Rumah sakit Tiara Pematangsiantar secara simultan maupun parsial.

\section{Metode Penelitian}

Penelitian ini mengambil lokasi di Rumah sakit Tiara Pematangsiantar yang berlokasi di Jalan Menambin No 4, Kelurahan Timbang Galung Kecamatan Siantar Barat, Kota Pematangsiantar. Pada penelitian ini yang menjadi populasi adalah para pasien Rumah Sakit Tiara Pematangsiantar yang memiliki 3.950 pasien dari bulan Januari 2014 sampai dengan Desember 2014 dengan rata-rata perbulan 329 pasien yang diambil dari data pasien yang melakukan rawat inap di Rumah sakit Tiara Pematangsiantar.

Adapun Desain penelitian yang digunakan dalam penulisan penelitian ini adalah Penelitian Kepustakaan (Library Research) dan Penelitian Lapangan (Field Research). Teknik pengumpulan data yang dilakukan penulis dalam penelitian ini adalah berupa Observasi, Kuesioner, Wawancara dan Dokumentasi. Adapun jenis data yang digunakan dalam penelitian ini adalah jenis data kualitatif dan data kuantitatif. Hasil data yang diperoleh dari lapangan akan dianalisis secara deskriptif baik bersifat kualitatif dan kuantitatif.

\section{B. LANDASAN TEORI}

1. Manajemen Pemasaran

Menurut Kotler dan Gary (2004:16), manajemen pemasaran adalah analisis, perencanaan, implementasi, dan pengendalian terhadap program yang dirancang untuk menciptakan, membangun dan mempertahankan pertukaran dan hubungan yang menguntungkan dengan pasar sasaran dengan maksud untuk mencapai tujuan-tujuan organisasi. Sedangkan manajemen pemasaran menurut Tjiptono (2002:16), yaitu proses perencanaan dan pelaksanaan konsep penentuan harga, promosi, dan distribusi barang, jasa dan gagasan untuk menciptakan pertukaran dengan kelompok sasaran yang memenuhi tujuan pelanggan dan organisasi. Dari definisi diatas, dapat disimpulkan bahwa manajemen pemasaran adalah suatu kegiatan yang dirancang untuk menawarkan produk atau jasa kepada konsumen guna untuk mencapai tujuan organisasi.

\section{Jasa atau Pelayanan}

Menurut Tjiptono (2011:15), jasa merupakan aktivitas, manfaat atau kepuasan yang ditawarkan untuk di jual. Menurut Kotler (2002:83), pelayanan adalah setiap tindakan atau kegiatan yang dapat ditawarkan oleh suatu pihak kepada pihak lain, yang pada dasarnya tidak berwujud dan tidak mengakibatkan kepemiliknya apapun. Dari beberapa pengertian jasa diatas, maka dapat disimpulkan bahwa jasa adalah setiap tindakan atau kinerja yang ditawarkan dari suatu pihak-pihak lain yang pada dasarnya jasa itu tidak berwujud tanpa adanya kepemilikan dan dapat ditawarkan kepada pihak lain, memberikan manfaat-manfaat bagi pihak terkait.

Menurut Parasuraman, Zeithaml dan Berry dalam Tjiptono dan Gregorius (2011:198), terdapat lima dimensi kualitas pelayanan yaitu Tangibles, Reliability, Responsiveness, Assurance, dan Empathy.

\section{Kepuasan Pelanggan}

Menurut Gerson (2002:112), kepuasan pelanggan adalah persepsi bahwa harapannya telah terpenuhi atau terlampui, dan sebaliknya jika pelanggan tidak puas, dia akan menghentikan bisnisnya dengan perusahaan. Menurut Kotler (2007:13), kepuasan pelanggan bergantung pada perkiraan kinerja produk dalam memberikan nilai relatif kepada harapan pelanggan. Dari beberapa pengertian kepuasan pelanggan, maka dapat disimpulkan bahwa kepuasan pelanggan adanya perbandingan antara harapan hasil kinerja yang dirasakan pelanggan, sehingga pelanggan merasa puas.

Menurut Irawan (2003:332), ada empat atribut utama kepuasan pelanggan yaitu: kualitas produk, harga, kemudahan dan faktor emosional (emotional factor).

\section{Loyalitas Pelanggan}

Menurut Lupioyandi dan Hamdani (2006:193), loyalitas adalah komitmen yang 
dipegang kuat untuk membeli ulang atau berlangganan lagi produk atau jasa tertentu dimasa depan meskipun ada pengaruh situasi yang menyebabkan peralihan perilaku. Menurut Griffin (2003:31), loyalitas merupakan perilaku membeli, pelanggan yang loyal adalah melakukan pembelian berulang secara teratur, membeli antar lini produk dan jasa, mereferensikan kepada orang lain, menunjukkan kekebalan terhadap tarikan dari pesaing. Dari definisi diatas dapat disimpulkan bahwa loyalitas konsumen merupakan bukti bahwa konsumen tersebut setia kepada perusahaan dan suatu keinginan konsumen untuk melakukan pembelian yang berulang-ulang.

Empat jenis loyalitas yang berbeda yang muncul bila keterikatan rendah dan tinggi diklasifikasikan silang dengan pola pembelian berulang menurut Griffin (2003:22), yaitu loyalitas yang lemah, loyalitas premium, tanpa loyalitas dan loyalitas tersembunyi.

\section{Pengaruh Kualitas Pelayanan dan} Kepuasan Pelanggan Terhadap Loyalitas

Menurut Tjiptono (2008:121), kualitas pelayanan merupakan sebagai ukuran seberapa bagus tingkat layanan yang diberikan mampu sesuai dengan ekspetasi. Menurut Kotler dan Kevin (2007:255), menyatakan bahwa kualitas pelayanan berpengaruh dan kepuasan konsumen akan menentukan minat membeli atau menggunakan kembali suatu produk/jasa. Jadi dapat disimpulkan kualitas pelayanan dan kepuasan secara bersamasama berpengaruh signifikan terhadap loyalitas.

\section{PEMBAHASAN}

\section{Analisa}

\section{a. Deskriptif Kualitatif}

Adapun penetapan kriteria nilai rata-rata jawaban dari responden tersebut dimasukan kedalam kelas-kelas interval dimana penetuan intervalnya memakai rumus sebagai berikut:

$$
\begin{aligned}
\text { Inteival kelas } & =\frac{\text { Nilai Tertinad }- \text { Nilai Terendah }}{(\text { (umlab kalsa ntevial) }}=\frac{5-1}{5} \\
& =0,8
\end{aligned}
$$

Dari rumus diatas dapat diperoleh interval kelas 0,8 sehingga berlaku ketentuan kategori dengan hasil sebagai berikut:

$$
\text { Tabel } 1
$$

\begin{tabular}{|c|c|c|c|}
\hline \multirow[t]{2}{*}{ 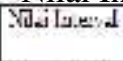 } & \multicolumn{3}{|c|}{ Eat:yuL } \\
\hline & Fuates l'avanax & Setuasin. Jelengaza & 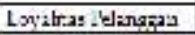 \\
\hline $1(11-1)$ & 5xาg - $1=k$ latk & !arget limsah letrah & iargatliruhleckalh \\
\hline $1.31-2.60$ & Lidak D:ak & "aragit Haclah & jargat Ractah \\
\hline $\begin{array}{l}51-41 \\
:-1\end{array}$ & $\begin{array}{l}\text { Ciknt li=rs } \\
\text { Rai: }\end{array}$ & timn rzg & $\begin{array}{l}\text { Trkn } \\
\text { Trgy }\end{array}$ \\
\hline unbente & rasit,pengo & andata & Saryial Tulapi \\
\hline
\end{tabular}

\section{1) Kualitas Pelayanan di Rumah Sakit Tiara \\ Pematangsiantar}

Dari tabel total jawaban dapat dilihat bahwa pada dimensi kemampuan (reliability), indikator ketepatan perawat dalam melayani pasien memiliki nilai rata-rata 3,50 memiliki kriteria baik karena ketepatan dalam melayani pasien merupakan kebutuhan seorang pasien. Pada indikator tentang kesiapan dalam menangani keluhan pasien diperoleh nilai rata-rata 3,76 dan dikatagorikan baik sesuai dengan kriteria, karena perawat diharuskan memiliki kesiapan dalam menangani segala keluhan pasien. Kemudian pada indikator tentang keterampilan petugas dalam menggunakan peralatan medis, nilai rata-rata 3,89 yang kriterianya baik, karena petugas telah diberikan pelatian dalam menggunakan peralatan medis untuk mendukung kesehatan pasien secara baik.

Pada dimensi daya tanggap (responsiveness), indikator tentang kecepatan dokter dalam melakukan visite terhadap pasien dengan nilai rata-rata 3,62 yang kriterianya baik, karena setiap dokter sangat diharapkan pasien dalam mengobati penyakit yang diderita. Pada indikator tentang ketanggapan dokter dalam mengatasi keluhan pasien diperoleh nilai ratarata 3,86 yang kriterianya baik, dikarenakan pasien sangat mengharapkan anjuran-anjuran dokter dalam memelihara kesehatan pasien. Pada indikator tentang pemberian informasi secara cepat dengan nilai ratarata 3,87 yang kriterianya baik, karena informasi yang diberikan perawat dapat memberikan ketenangan bagi pasien.

Pada dimensi jaminan (assurance), pada indikator tentang ketepatan dalam memberikan hasil pemeriksaan penunjang kesehatan dengan nilai ratarata 3,89 yang kriterianya baik, karena hasil pemeriksaan sangat di perlukan dalam menegakkan diagnosa dokter. Pada indikator tentang reputasi petugas dalam memberikan pelayanan memiliki nilai rata-rata 3,87 yang kriteria baik, karena petugas mengetahui keinginan dari pasien dalam memberikan pelayanan. Kemudian pada indikator tentang penyampaian komunikasi dengan nilai ratarata diperoleh 3,76 yang kriteria baik karena penyampaian komunikasi yang tepat dari seorang petugas pasien dengan mudah untuk mengetahui maksud dan tujuan komunikasi tersebut.

Pada dimensi empati (emphaty), indikator tentang kemampuan dokter dalam berkomunikasi dengan pasien diperoleh nilai rata-rata 3,68 yang kriteria baik, karena informasi yang diberikan oleh dokter dapat memberikan kenyamanan terhadap pasien. Pada indikator tentang perhatian dokter terhadap keluhan pasien dengan nilai rata-rata 3,68 yang kriterianya baik karena perhatian dokter dapat memberikan kesenangan terhadap pasien yang di tanganinya. Pada indikator tentang tidak membedabedakan pasien diperoleh nilai rata-rata 3,88 yang kriteria baik, karena setiap pasien sama dimata dokter untuk mendapatkan pengobatan yang baik untuk kesehatan pasiennya.

Pada dimensi bukti fisik (tangibles), indikator tentang penampilan petugas rumah sakit Tiara diperoleh nilai rata-rata 3,50 yang kriteria baik, karena penampilan yang rapi, bersih dapat memberikan nilai positif terhadap pasien yang dirawat. Pada indikator tentang sarana dan prasarana fisik di rumah sakit Tiara diperoleh nilai rata-rata 3,77 yang kriteria baik, dikarenakan sarana dan prasarana merupakan faktor pendukung dalam memberikan pelayanan kesehatan pasien. Kemudian 
pada indikator tentang kelengkapan peralatan medis di rumah sakit tiara diperoleh nilai rata-rata 3,50 dengan kriteria baik, karena perlengkapan peralatan dapat menjadi faktor pendukung dalam memberikan kualitas pelayanan terhadap pasien.

Dari semua pertanyaan tersebut dapat disimpulkan bahwa dimensi-dimensi kualitas pelayanan di peroleh nilai rata-rata 3,73. Nilai tertinggi terdapat dimensi kemampuan (reliability) pada indikator tentang keterampilan petugas menggunakan peralatan medis pada RS Tiara memperoleh 3,89. Sedangkan nilai terendah terdapat dimensi daya tanggap (responsiveness) pada indikator tentang kecepatan dokter dalam melakukan visite memperoleh 3,62, dimensi jaminan (assurance), indikator tentang penyampaian komunikasi kepada pasien memperoleh 3,76, dimensi empati (emphaty) pada indikator tentang perhatian dokter terhadap keluhan pasien memperoleh nilai 3,67 dan dimensi bukti fisik (tangibles) pada indikator tentang penampilan petugas memperoleh nilai 3,50 terendah.

\section{2) Kepuasan Pelanggan di Rumah Sakit Tiara Pematangsiantar}

Dari tabel jawaban responden dapat dilihat bahwa pada dimensi kualitas jasa indikator tentang kualitas peralatan medis yang digunakan petugas pada Rumah sakit Tiara memiliki nilai rata-rata 3,50 dengan kriteria tinggi karena peralatan medis yang ada di rumah sakit tiara memiliki bentuk, kecanggihan alat $\mathrm{Ct}$ - Scan, ventilator, monitor jantung, rongent, dan alat-alat laboratorium yang diberikan sesuai dengan yang diharapkan. Pada indikator tentang penampilan peletakkan peralatan medis diperoleh nilai rata-rata 3,61 yang kriteria tinggi, karena kualitas peletakkan peralatan medis yang strategis. Pada indikator tentang bentuk-bentuk peralatan medis di rumah sakit tiara diperoleh nilai rata-rata 3,70 dengan kriteria tinggi, karena bentukbentuk peralatan medis yang terbaru sehingga dapat dengan mudah untuk menegakkan diagnosa dokter.

Pada dimensi harga produk atau jasa pada indikator tentang pihak manajemen rumah sakit Tiara dalam menentukan harga yang diperoleh nilai rata-rata 3,52 dengan kriteria tinggi karena harga yang ditentukan pihak rumah sakit tiara sangat terjangkau bagi pasien, seperti memberikan paket operasi. Pada indikator tentang kesesuaian harga dengan pelayanan diperoleh nilai rata-rata 3,54 dengan kriteria tinggi karena harga yang diberikan sesuai dengan pelayanan yang diberikan pihak rumah sakit, seperti harga untuk Ct-Scan yang sesuai dengan kecanggihan alat. Pada indikator tentang tingkat pemberian harga perobatan diperoleh nilai rata-rata 3,68 dengan kriteria tinggi karena pihak rumah sakit memberikan keterjangkauan untuk berobat.

Pada dimensi kemudahan indikator tentang tingkat kenyamanan pelayanan diperoleh nilai ratarata 3,74 dengan kriteria tinggi, karena pelanggan merasa nyaman dalam mendapatkan pelayanan kesehatan. Pada indikator tentang kemudahan dalam pembayaran rekening perobatan diperoleh nilai ratarata 3,75 dengan kriteria tinggi, karena pasien tidak merasa rumit dalam pembayaran dan tidak berteletele dalam pembayaran. Kemudian pada indikator tentang kemudahan mendapatkan informasi diperoleh nilai rata- rata 3,87 dengan kriteria tinggi karena pasien lebih mudah mendapatkan informasi pelayanan kesehatan.

Pada dimensi faktor emosional pada indikator tentang tingkat kebanggaan terhadap pelayanan yang diberikan diperoleh nilai rata-rata 3,55 dengan kriteria tinggi karena pelanggan merasa bangga atas pelayanan yang diberikan sesuai dengan harapan mereka. Pada indikator tentang rasa percaya diri pasien terhadap pelayanan kesehatan yang diberikan dapat diperoleh nilai rata-rata 3,64 dengan kriteria tinggi karena pasien merasa percaya dalam mendapatkan pelayanan jasa. Kemudian pada indikator tentang hubungan pasien dengan petugas RS Tiara diperoleh nilai rata-rata 3,92 dengan kriteria tinggi yaitu hubungan pasien dengan petugas rumah sakit yang terjalin dengan baik.

Dari semua pertanyaan tersebut dapat disimpulkan bahwa dimensi-dimensi kepuasan pelanggan dinilai dengan rata-rata 3,67. Nilai tertinggi dapat dilihat pada dimensi faktor emosional pada indikator hubungan pasien dan petugas diperoleh nilai rata-rata 3,92. Sedangkan nilai terendah dapat dilihat pada dimensi kualitas jasa pada indikator kualitas peralatan medis yang digunakan diperoleh nilai rata-rata 3,50. Pada dimensi harga pada indikator pihak rumah sakit dalam menentukan harga diperoleh nilai rata-rata 3,50. Sedangkan pada dimensi kemudahan pada indikator kenyamanan pasien dalam mendapatkan perawatan diperoleh nilai rata-rata 3,74 dinilai kriteria tinggi.

\section{3) Loyalitas Pasien Rawat Inap di RS Tiara Pematangsiantar}

Dari jawaban responden dapat dilihat bahwa pada dimensi melakukan pembelian ulang yang teratur pada indikator tentang pembelian pelayanan kesehatan yang berulang (pasien berulang) yang diberikan diperoleh nilai rata-rata 3,50 dan dikatagorikan tinggi, karena keunggulan dan kualitas yang diberikan kepada pasien, membuat pasien merasa puas dalam mendapatkan pelayanan kesehatan di rumah sakit Tiara. Pada bulan Juni dan Juli pasien berulang di rumah sakit Tiara sebanyak 8 orang. Pada indikator tentang kesediaan pasien menjaga hubungan terhadap pelayanan kesehatan yang ditawarkan rumah sakit Tiara memiliki nilai rata-rata 3,75 dengan kriteria tinggi, karena sikap dan pelayanan yang diberikan tenaga medis kepada pasien memuaskan sehingga, pasien dan pihak rumah sakit terjalin hubungan yang baik. Pada indikator tentang kualitas pelayanan yang diberikan petugas medis/non medis diperoleh nilai rata-rata 3,81 dengan kriteria tinggi, karena pasien selalu mengharapkan kualitas pelayanan yang diberikan petugas medis/non medis sesuai dengan harapan pasien dalam merawat kesehatan pasien. 
Pada dimensi membeli antar lini produk dan jasa pada indikator tentang pembelian pelayanan kesehatan pasien terhadap pelayanan jasa yang beragam diperoleh nilai rata-rata 3,67 dengan kriteria tinggi, karena rumah sakit Tiara selalu memberikan pelayanan kesehatan yang diharapkan pasien. Pada indikator tentang respon pasien terhadap pelayanan kesehatan rumah sakit Tiara diperoleh nilai rata-rata 3,72 dengan kriteria tinggi, karena pihak rumah sakit tiara selalu memberikan kenyamanan, kepuasan dan kualitas pelyanan terhadap pasien sehinngga respon yang diberikan pasien terhadap rumah sakit tiara sangat baik. Kemudian pada indikator tentang membandingkan pelayanan kesehatan rumah sakit Tiara dengan rumah sakit lainnya diperoleh nilai rata-rata 3,70 dengan kriteria tinggi, karena pasien sangat teliti dalam memilih rumah sakit untuk memelihara kesehatan pasien sehingga rumah sakit tiara menunjukkan keunggulan dalam melayani pasien.

Pada dimensi mereferensikan kepada orang lain pada indikator tentang pasien mereferensikan pelayanan kesehatan kepada orang lain diperoleh nilai rata-rata 3,89 dengan kriteria tinggi karena pasien memperoleh kualitas pelayanan dan kepuasan pelayanan sehingga pasien dengan sukarela merekomendasikan rumah sakit Tiara kepada rekanrekannya. Pada indikator tentang memberikan informasi kepada orang lain diproleh nilai rata-rata 3,76 dikatagorikan tinggi, karena pasien telah mendapatkan kualitas pelayanan dan kenyamanan yang sesuai dengan harapan mereka sehingga pasien dengan suka rela memberikan informasi yang baik kepada orang lain. Kemudian pada indikator tentang cara mempengaruhi orang untuk menggunakan jasa kesehatan rumah sakit tiara diperoleh nilai rata-rata 3,73 dengan kriteria tinggi, karena Rumah sakit Tiara telah memberikan kepuasan pelayanan yang sesuai harapan pasien sehingga, pasien dengan mudah untuk mempengaruhi orang untuk menggunakan jasa rumah sakit tiara.

Pada dimensi menunjukkan kekebalan terhadap pesaing pada indikator tentang keyakinan pasien terhadap rumah sakit tiara diperoleh nilai ratarata 3,66 dengan kriteria tinggi, karena keyakinan pasien merupakan hal yang penting untuk rumah sakit tiara dalam menjaga kualitas pelayanan dengan pesaing yang sejenis. Pada indikator tentang konsistensi pelayanan jasa kesehatan ditengah tawaran dari rumah sakit lainnya diperoleh nilai ratarata 3,75 dengan kriteria tinggi, karena rumah sakit tiara konsisten dengan pelayanan yang diberikan sehingga, rumah sakit tiara tidak merasa kalah dengan rumah sakit lainnya karena, rumah sakit tiara memiliki keunggulan yang dibanggakan. Kemudian pada indikator tentang mempertahankan keunggulan rumah sakit tiara diperoleh nilai rata-rata 3,88 dengan kriteria tinggi karena, kualitas pelayanan, kepuasan dan kenyamanan yang diberikan merupakan cara untuk mempertahankan kualitas rumah sakit tiara dengan rumah sakit lainnya.

Dari semua pertanyaan diatas dapat disimpulkan bahwa dimensi-dimensi loyalitas pelanggan dinilai dengan nilai rata-rata 3,73. Nilai tertinggi pada dimensi mereferensikan kepada orang lain indikator tentang pasien dalam mereferensikan pelayanan pada rumah sakit tiara diperoleh 3,89. Sedangkan nilai terendah dimensi melakukan pembelian ulang pada indikator pembelian pelayanan kesehatan diperoleh nilai rata-rata 3,50. Pada dimensi membeli antar lini produk dan jasa pada indikator pembelian pelayanan yang dilakukan pasien dengan pelayanan beragam diperoleh nilai rata-rata 3,67. Sedangkan pada dimensi menunjukkan kekebalan terhadap pesaing indikator tentang keyakinan pasien terhadap keunggulan pelayanan diperoleh nilai rata-rata 3,66.

\section{b. Deskriptif Kuantitatif \\ 1) Regresi Linear Berganda}

Analisis regresi linier berganda digunakan untuk mengetahui pengaruh variabel bebas (X) dan variabel terikat (Y), dimana $\mathrm{X} 1$ adalah kualitas pelayanan, X2 kepuasan pelanggan dan $\mathrm{Y}$ adalah loyalitas. Maka dilakukan perhitungan menggunakan program aplikasi SPSS untuk memperoleh nilai a dan $b$ dengan notasi sebagai berikut: $\hat{Y}=a+b_{1} X_{1}+$ $\mathrm{b}_{2} \mathrm{X}_{2}$

Tabel 2

Regresi Linier Berganda Coefficients $^{a}$

\begin{tabular}{|c|c|c|c|c|}
\hline \multirow{2}{*}{\multicolumn{2}{|c|}{$V m i=1$}} & \multicolumn{2}{|c|}{ 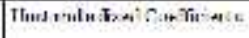 } & \multirow{2}{*}{ 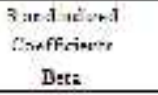 } \\
\hline & & 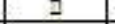 & st: $=\pi n$ & \\
\hline \multirow{3}{*}{1} & (Cimetionf) & $0,4: 25$ & $26: 5$ & \\
\hline & 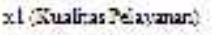 & . 253 & $\mathrm{CH}$ & .373 \\
\hline & 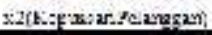 & 205 & $\Leftrightarrow \Leftrightarrow$ & $\ldots 4$ \\
\hline
\end{tabular}

a. Dependent Variable: Loyalitas Pelanggan (Y)

Sumber: hasil perhitungan SPSS Statistics 17.00

Dari hasil perhitungan analisis regresi degan SPSS diperoleh konstan sebesar 9,435 dan koefisien regresi $\mathrm{X}_{1}$ sebesar 0,428 dan $\mathrm{X}_{2}$ sebesar 0,267 sehingga dapat diketahui persamaan regresi yang diperoleh adalah : $\hat{Y}=9,435+0,428 X_{1}+0,267 X_{2}$. Dari persamaan regresi tersebut dapat dijelaskaan kualitas pelayanan (X1) dan kepuasan pelanggan (X2) berpengaruh positif terhadap loyalitas pelanggan $(\mathrm{Y})$.

\section{2) Analisis Korelasi dan Koefisien Determinan}

Untuk mengetahui kekuatan hubungan kualitas pelayanan dan kepuasan pelanggan terhadap loyalitas dapat dihitung menggunakan SPSS sebagai berikut:

Tabel 3

Koefisien Korelasi dan Koefisien Determinasi Model Summary ${ }^{b}$

\begin{tabular}{|c|c|c|c|}
\hline \multicolumn{4}{|c|}{ Model Summary ${ }^{b}$} \\
\hline 2Node] & $\pi$ & 2 Squar: Adutrect.Squar & Std Inet situr Ir:inuat: \\
\hline 1 & ;n $=$ & +997 & 4 \\
\hline
\end{tabular}

a. Predictors: (Constant), Kualitas Pelayanan dan Kepuasan Pelanggan

b. Dependent Variable: Loyalitas Pelanggan

Sumber:hasil perhitungan dengan SPSS Statitistic 17

Dari tabel diatas didapat nilai $r=0,705$ yang terdapat hubungan yang kuat dan positif antara kualitas pelayanan dan kepuasan pelanggan terhadap loyalitas pasien rawat inap di Rumah sakit Tiara 
Pematangsiantar. Hal ini dikarenakan pasien sering memperhatikan kualitas pelayanan yang diberikan Rumah sakit Tiara Pematangsiantar dan tingkat kepuasan pasien. Kemudian diperoleh koefisien determinassi ( $R$ square) 0,497 yang artinya tinggi rendahnya loyalitas pasien dapat dijelaskan sebesar $49,7 \%$ oleh kualitas pelayanan dan kepuasan pasien sisanya $50,3 \%$ dijelaskan oleh faktor-faktor lain seperti harga maupun promosi yang tidak dibahas dalam penelitian ini.

\section{3) Uji Simultan (Uji F)}

Pengujian ini dilakukan untuk membandingkan antara $F_{\text {hitung }}$ dan $F_{\text {tabel }}$ pada taraf signifikansi sebesar $5 \%$ atau $\alpha=0,05$ dengan menggunakan program aplikasi SPSS sebagai berikut:

Tabel 4

Perkiraan Nilai F hitung

ANOVA ${ }^{a}$

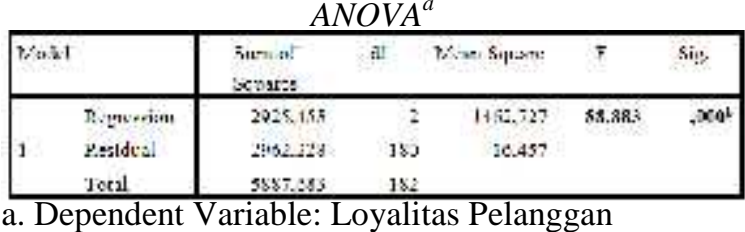

b. Predictors: (Constant): Kualitas Pelayanan dan Kepuasan Pelanggan

Sumber: hasil perhitungan SPSS Statistics 17.0

Dari perhitungan diatas dapat dilihat nilai $\mathrm{F}_{\text {hitung }} 88,883>\mathrm{F}_{\text {tabel }}$ dengan tingkat signifikan $5 \%$ $\mathrm{F}_{(0,05 ; 2}$ vs 180) adalah sebesar 3,05 atau dengan signifikan $0,000 \quad 0,05$ maka $\mathrm{H}_{0}$ ditolak artinya, kualitas pelayanan dan kepuasan pelanggan secara bersama-sama atau simultan memiliki pengaruh terhadap Loyalitas pasien rawat inap di Rumah sakit Tiara Pematangsiantar.

\section{4) Uji Parsial (Uji t)}

Dari hasil perhitungan koefisien korelasi diketahui bahwa kualitas pelayanan, kepuasan pelanggan dan loyalitas pelanggan sangat berhubungan, untuk menguji kebenarannya maka dilakukan pengujian hipotesis dengan mengunakan program aplikasi SPSS.

Tabel 5

Perkiraan Nilai thitung

Coefficients $^{a}$

\begin{tabular}{|c|c|c|}
\hline \multicolumn{3}{|c|}{ Coefficients ${ }^{a}$} \\
\hline Mestef & t & nis \\
\hline (Saresich & $3: 12$ & .062 \\
\hline 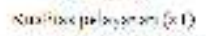 & v. .20 & 1.00 \\
\hline 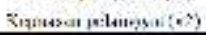 & 3908 & siten \\
\hline
\end{tabular}

a. Dependent Variable: loyalitas pelanggan (y) Sumber: Hasil perhitungan SPSS Statistics 17.0

Dari tabel diatas dapat dilihat variabel $X_{1}$ nilai $\mathrm{t}_{\text {hitung }} 9,790>\mathrm{t}_{\text {tabel }}$ dan variabel $\mathrm{X}_{2}$ nilai $\mathrm{t}_{\text {hitung }}$ $3,998>t_{\text {tabel }}$ dengan derajat bebas $\mathrm{df}=\mathrm{n}-\mathrm{k}-1$ (183-2 1) sebesar 1,97323 , atau dengan taraf signifikan $X_{1}$ $0,000 \quad 0,05$ maka $\mathrm{H}_{0}$ ditolak, artinya kualitas pelayanan berpengaruh positif dan signifikan terhadap loyalitas. Signifikan $X_{2} 0,000 \quad 0,05$ maka $\mathrm{H}_{0}$ ditolak artinya, kepuasan pelanggan berpengaruh positif dan signifikan terhadap loyalitas pasien rawat inap di Rumah sakit Pematangsiantar secara parsial.

\section{Evaluasi}

\section{a. Kualitas Pelayanan Rumah Sakit Tiara}

\section{Pematangsiantar}

Berdasarkan hasil analisis, dapat dilihat bahwa kualitas pelayanan pada rumah sakit Tiara Pematangsiantar sudah baik. Hal tersebut terlihat dari jawaban 183 responden yang dibagikan penulis, dimana diperoleh nilai rata-rata 3,73 yang dinilai baik. Tetapi pada dimensi kemampuan (reliability), masih dibawah nilai rata-rata yaitu pada indikator tentang ketepatan perawat dalam melayani pasien dengan nilai rata-rata 3,50, indikator tentang kesiapan dalam menangani keluhan pasien dengan nilai rata-rata 3,76. Sehingga cara memperbaiki yaitu pimpinan mengadakan briffing sehingga, petugas medis mendapatkan saran, masukkan yang lebih baik dan petugas medis mengikuti seminar yang diadakan Dinas Kesehatan Kota maupun Dinas Kesehatan Provinsi.

Pada dimensi daya tanggap (responsiveness), pada indikator tentang kecepatan dokter dalam melakukan visite dengan nilai rata-rata 3,62 di nilai masih dibawa rata-rata. Sehingga cara memperbaikinya yaitu pimpinan harus mencari dokter yang memiliki SIP (surat izin praktek), tetap di rumah sakit Tiara bukan hanya dengan nota tugas. Sehingga dokter-dokter tersebut standby di poliklinik dengan jadwal yang telah ditetapkan pihak rumah sakit Tiara.

Pada dimensi jaminan (assurance) pada indikator tentang penyampaian komunikasi kepada pasien memperoleh nilai rata-rata 3,76 yang kriterianya baik, namun masih dibawah rata-rata. Cara memperbaikinya yaitu petugas medis/non medis perlu diberikan saran dalam melayani setiap menyampaikan komunikasi kepada pasien maupun keluarga pasien. Petugas medis/non medis juga diberikan pelatihan tentang cara-cara penyampaian komunikasi yang baik dan sopan. Sehingga pasien dapat mengerti apa yang disampaikan oleh petugas medis/non medis.

Pada dimensi empati (emphaty),pada indikator tentang kemampuan dokter dalam berkomunikasi dengan pasien memperoleh nilai ratarata 3,68 yang kriterianya baik, namun masih dibawah rata-rata. Cara memperbaikinya yaitu, pihak manajemen menegur dokter apa bila pasien mengeluh tentang penyampaian komunikasi yang dilakukan tidak baik. Pada indikator tentang perhatian dokter terhadap keluhan pasien diperoleh nilai rata-rata 3,67 yang kriterianyan baik, namun masih dibawa rata-rata. Cara memperbaikinya yaitu, pihak manajemen rumah sakit memberikan arahan kepada dokter, karena memberikan perhatian terhadap keluhan pasien merupakan pelayanan yang diharapkan pasien dalam menjalani pengobatan.

Pada dimensi bukti fisik (tangibles), pada indikator tentang penampilan petugas Rumah sakit Tiara diperoleh nilai rata-rata 3,68 dengan kriteria tinggi, namun masih dibawah nilai rata-rata. Cara 
memperbaikinya yaitu petugas medis/non medis memiliki baju seragam setiap harinya, dengan membedakan keperawatan, kebidanan dan administrasi dengan memakai kap, rapi, dan harum. Pada indikator tentang sarana dan prasarana fisik di Rumah sakit Tiara memperoleh nilai rata-rata 3,77 dengan kriteria tinggi, namun masih biwah rata-rata. Pada indikator tentang kelengkapan peralatan medis di Rumah sakit Tiara memperoleh nilai rata-rata 3,50 dengan kriterianya tinggi, namun masih dibawah rata-rata. Cara memperbaikinya yaitu, Rumah sakit Tiara menambah lagi peralatan medis untuk menunjang pelayanan kesehatan sesuai dengan tipe penetapan kelas. Seperti menambah alat Hemodialisa, ECG, Indoscopy, coloncopy dan alat laboratorium patalogi anatomi.

\section{b. Kepuasan Pelanggan pada Rumah Sakit Tiara Pematangsiantar}

Berdasarkan hasil analisis, kepuasan pelanggan pada rumah sakit Tiara sudah tinggi. Hal ini dapat dilihat dari nilai rata-rata jawaban sebesar 3,67. Namun ada beberapa indikator yang masih dibawah rata-rata yaitu pada dimensi kualitas produk/jasa pada indikator tentang kualitas peralatan medis yang digunakan diperoleh nilai rata-rata 3,50 masih dibawah rata-rata cara memperbaikinya adalah pihak rumah sakit lebih sering untuk maintenance peralatan. Pada indikator tentang penampilan peletakkan peralatan memperoleh nilai rata-rata 3,61 dengan kriteria tinggi, namun masih dibawah nilai rata-rata. Cara memperbaikinya adalah pihak rumah sakit Tiara menambah ruangan untuk meletakan setiap peralatan medis yang strategis sehingga, pasien yang akan melakukan pemeriksaan medis tidak merasakan kesulitan.

Pada dimensi harga pada indikator tentang pihak manajemen dalam menentukan harga pengobatan diperoleh nilai rata-rata 3,52 masih dibawah rata-rata cara memperbaikinya pimpinan harus membandingkan harga-harga pengobatan di rumah sakit lainnya dengan rumah sakit Tiara. Pada indikator tentang kesesuaian harga yang diberikan dengan pelayanan diperoleh nilai rata-rata 3,54 dengan kriteria tinggi, namun masih dibawah nilai rata-rata. Cara memperbaikinya adalah pihak rumah sakit lebih mengkaji ulang pelayanan yang diberikan, sehingga dapat menetapkan harga pengobatan.

Kemudian pada dimensi faktor emosional indikator tentang rasa bangga yang didapatkan pasien dalam melakukan pengobatan di Rumah sakit Tiara diperoleh nila rata-rata 3,55 dan indikator tentang rasa percaya diri pasien mendapatkan pengobatan pada Rumah sakit Tiara diperoleh nilai rata-rata 3,64 masih dibawah rata-rata. Cara memperbaikinya yaitu pihak rumah sakit menerangkan grafik kesembuhan pasien setiap bulannya. Sehingga pasien merasa bangga dan percaya bahwa berobat dirumah sakit Tiara akan mendapatkan kesembuhan secara total dan akan menjalin hubungan yang baik antara pasien dengan pihak rumah sakit tiara.

\section{c. Loyalitas Pelanggan pada Rumah Sakit Tiara Pematangsiantar}

Dalam pelaksanaannya, loyalitas pelanggan pada rumah sakit Tiara sudah baik. Hal ini dapat dilihat dari nilai rata-rata yang diperoleh adalah 3,73 dikatagorikan tinggi. Namun ada beberapa dimensi yang masih dibawah rata-rata yaitu pada dimensi melakukan pembelian ulang (pasien berulang), indikator tentang pasien berulang pada rumah sakit Tiara diperoleh nilai rata-rata 3,50 masih dibawah rata-rata cara memperbaikinya pimpinan pihak rumah sakit lebih meningkatkan kualitas pelayanan seperti, kemampuan petugas medis/non medis lebih ditingkatkan, daya tanggap petugas dalam melayani keluhan pasien, penambahan peralatan medis yang lebih lengkap, sehingga pasien tidak merasa rugi berobat di rumah sakit Tiara.

Pada dimensi membeli antar lini produk/jasa indikator tentang pembelian pelayanan jasa kesehatan yang dilakukan pasien terhadap pelayanan kesehatan yang beragam diperoleh nilai rata-rata 3,67. Cara memperbaikinya pada yaitu pihak rumah sakit lebih menambah lagi produk jasa seperti membuat paket untuk cek up, menambah lagi jenis pemeriksaan laboratorium jenis pemeriksaan patologi dan anatomi. Sehingga jasa yang diberikan rumah sakit Tiara lebih beragam

Pada dimensi menunjukkan kekebalan terhadap pesaing pada indikator tentang keyakinan pasien terhadap keunggulan pelayanan kesehatan rumah sakit Tiara diperoleh nilai rata-rata 3,66 dengan kriteria tinggi, namun masih dibwah ratarata. Cara memperbaiki yaitu pihak rumah sakit lebih meningkatkan presentasi kesembuhan pasien dengan memberikan keunggulan-keunggulan berobat di rumah sakit Tiara. Sehingga pasien yakin dan membandingkan dengan rumah sakit lainnya.

\section{KESIMPULAN DAN SARAN}

1.Kesimpulan

a. Hasil analisis deskriptif kualitatif tentang kualitas pelayanan dari dimensi, kemampuan (reliability), daya tanggap (responsiveness), jaminan (assurance), empati (emphaty), dan bukti fisik (tangibles) diperoleh nilai rata-rata 3,73 dengan kriteria baik. Nilai tertinggi terdapat dimensi kemampuan (reliability), pada indikator tentang keterampilan petugas menggunkan peralatan medis memperoleh nilai rata-rata 3,89 . Sedangkan nilai terendah terdapat pada dimensi daya tanggap (responsiveness), pada indikator tentang kecepatan dokter dalam melakukan visite memperoleh 3,62. Dimensi jaminan (assurance), indikator tentang penyampaian komunikasi kepada pasien 3,76. Dimensi empati (emphaty), pada indikator tentang perhatian dokter tehadap keluhan pasien memperole nilai rata-rata 3,67 dan pada dimensi bukti fisik (tangibles), pada indikator tentang penampilan petugas memperoleh nilai rata-rata 3,50 terendah.

b. Hasil analisis deskriptif kualitatif tentang kepuasan baik dari dimensi kualitas jasa/produk, harga, kemudahan, faktor emosional diperoleh 
nilai rata-rata 3,67 dengan kriteria tinggi. Nilai tertinggi terdapat pada dimensi faktor emosional indikator tentang hubungan pasien dengan petugas dengan nilai rata-rata 3,92 dengan kriteria tinggi. Sedangkan nilai terendah pada dimensi harga indikator pertama dengan nilai rata-rata 3,52 dengan kriteria tinggi.

c. Hasil analisis deskriptif kualitas tentang loyalitas tinggi dari dimensi melakukan pembelian ulang, membeli antar lini produk/jasa, mereferensikan kepada orang lain dan menunjukkan kekebalan terhadap pesaing diperoleh nilai rata-rata 3,73 kriteria tinggi. Nilai tertinggi pada dimensi mereferensikan kepada orang lain indikator pertama dengan nilai rata-rata 3,89 kriteria tinggi. Sedangkan nilai terendahkan dimensi melakukan pembelian ulang indikator pertama dengan nilai rata-rata 3,50 kriteria tinggi.

d. Hasil analisis regresi linier berganda diperoleh persamaan $\hat{Y}=9.435+0,428 \mathrm{X}_{1}+0,267 \mathrm{X}_{2}$, artinya kualitas pelayanan $\left(\mathrm{X}_{1}\right)$, dan kepuasan $\left(\mathrm{X}_{2}\right)$ berpengaruh positif terhadap loyalitas $(\mathrm{Y})$ pada Rumah sakit Tiara Pematangsiantar.

e. Hasil analisis korelasi diperoleh nilai $r=0,705$ yang artinya terdapat hubungan yang kuat dan positif antara kualitas pelayanan dan kepuasan pelanggan terhadap loyalitas pasien pada rumah sakit Tiara Pematangsiantar. Koefisien determinasi (Rsquare/KD), sebesar 0,497 yang artinya tinggi rendahnya loyalitas pasien dapat dijelaskan $49,7 \%$ oleh kualitas pelayanan dan kepuasan, sisanya 50,3\% dijelaskan oleh faktorfaktor lain seperti promosi, harga dan lain sebagainya yang tidak dibahas dalam penelitian ini.

f. Dari hasil uji simultan (uji $F$ ) didapat $F_{\text {hitung }}$ $88,883>\mathrm{F}_{\text {tabel }} 3,05$ dan tingkat signifikan 0,000 0,05 artinya $\mathrm{H}_{0}$ ditolak, jika kualitas pelayanan dan kepuasan pelanggan berpengaruh positif dan signifikan terhadap loyalitas pasien rawat inap pada Rumah sakit Tiara Pematangsiantar.

g. Dari hasil uji parsial (uji t) didapat variabel $X_{1}$ nilai $t_{\text {hitung }} 9,790>t_{\text {tabel }}$ dan variabel $X_{2}$ nilai $t_{\text {hitung }}$ $3,998>\mathrm{t}_{\text {tabel }}$ dengan derajat bebas $\mathrm{df}=\mathrm{n}-\mathrm{k}-1$ (183-2-1), sebesar 1,97323 atau dengan taraf signifikan $\mathrm{X}_{1} \quad 0,000 \quad 0,05$ maka $\mathrm{H}_{0}$ ditolak artinya, kualitas pelayanan berpengaruh positif dan signifikan terhadap loyalitas. Signifikan $\mathrm{X}_{2}$ $0,000 \quad 0,05$ maka $\mathrm{H}_{0}$ ditolak artinya, kepuasan pelanggan berpengaruh positif dan signifikan terhadap loyalitas pasien rawat inap di Rumah sakit Pematangsiantar secara parsial.

\section{Saran}

a. Untuk meningkatkan, kualitas pelayanan pada dimensi daya tanggap (responsiveness), indikator tentang kecepatan dokter dalam melakukan visite dapat diperbaiki dengan cara mencari dokter yang memiliki SIP (surat izin praktek), tetap di Rumah sakit Tiara, bukan hanya dengan notas tugas. b. Untuk meningkatkan, kepuasan pasien dimensi kualitas jasa/produk indikator kualitas peralatan medis yang digunakan dapat memperbaiki dengan cara pihak Rumah sakit memperhatikan waktu dalam maintenance peralatan medis. Sedangkan pada dimensi harga indikator pihak rumah sakit dalam menentukan harga perobatan dapat diperbaiki dengan cara pimpinan harus membandingkan harga-harga pengobatan di Rumah sakit lainnya.

c. Untuk menciptakan, loyalitas dimensi melakukan pembelian ulang indikator tentang pembelian pelayanan kesehatan yang dilakukan pasien berulang dapat memperbaiki dengan cara meningkatkan kualitas pelayanan seperti, kemampuan petugas medis/non medis lebih ditingkatkan, daya tanggap petugas dalam melayani keluhan pasien, penambahan peralatan medis yang lebih lengkap, sehingga pasien tidak merasa rugi berobat di Rumah sakit Tiara.

d. Sehubungan dengan keterbatasan-keterbatasan yang ada pada penulis, penelitian ini masih terdapat kelemahan-kelemahan dan masih terdapat sejumlah variabel yang juga mempengaruhi loyalitas yang tidak digunakan didalam penelitian ini, seperti variabel perilaku konsumen yang meliputi sikap dan kepercayaan. Sebagai bahan masukan untuk penelitian selanjutnya, masih perlu memperbanyak variabel penelitian.

\section{E. DAFTAR PUSTAKA}

Gerson, Richard, F. 2002. Mengukur Kepuasan Pelanggan. Penerjemah Hesti Widyanigrum. Cetakan Kedua. Jakarta: Penerbit PPM.

Griffin. Jill. 2003. Costumer Loyalty Terj Dwi Kartini Yahya. Jakarta: Erlangga.

Irawan, Hadi. 2003. Kepuasan Pelayanan Jasa. Jakarta: Erlangga.

Kotler, Philip. 2002. Manajemen Pemasaran. Edisi Millennium. Jakarta: PT Prenhallindo.

2007. Manajemen Pemasaran. Edisi Keduabelas. Jakarta: PT Indeks.

Kotler, Philip dan Kevin Lane Keller. 2008. Manajemen Pemasaran. Edisi Dua Belas. Jilid I. Jakarta: PT indeks.

Kotler, Philip dan Gary Amstrong. 2004. DasarDasar Pemasaran. Edisi Kesembilan. Jakarta: PT Indeks.

Lupiyoadi, Rambat. 2006. Manajemen Pemasaran Jasa Teori dan Praktik,Jakarta: Salemba Empat.

Tjiptono. Fandy. 2002. Strategi Pemasaran. Edisi Dua. Yogyakarta: Penerbit Andi.

2008. Service Manajement, Edisi Lima. Yogyakarta: Andi

.......2011. Service Management Mewujudkan Layanan Prima. Edisi Dua. Yogyakarta: Andi.

Tjiptono, Fandy dan Gregorius Chandra. 2011. Service Quality \& Satisfaction. Edisi Ketiga. Yogyakarta: Andi. 